\title{
HEAT TRANSFER PROCESS DURING FILTRATION DRYING OF GRINDED SUNFLOWER BIOMASS
}

\author{
Diana Kindzera ${ }^{1,}{ }^{凶}$, Roman Hosovskyi ${ }^{1}$, Volodymyr Atamanyuk $^{1}$, Dmytro Symak $^{1}$
}

https://doi.org/10.23939/chcht15.01.118

\begin{abstract}
Filtration drying of grinded sunflower stems as the unit operation of the technological line for solid biofuel production has been proposed. Theoretical aspects of heat transfer processes during filtration drying have been analyzed. The effect of the drying agent velocity increase from 0.68 to $2.05 \mathrm{~m} / \mathrm{s}$ on the heat transfer intensity has been established. The values of heat transfer coefficients have been calculated on the basis of the thinlayer experimental data and equation $\alpha=\Delta Q / F \cdot\left(\bar{t}-\bar{T}_{p}\right) \cdot \Delta \tau$. Calculated coefficients for grinded sunflower stems have been correlated by the dimensionless expression $\mathrm{Nu}=0.3 \cdot \mathrm{Re}^{0.9} \cdot \mathrm{Pr}^{0.33}$ within Reynolds number range of $20 \leq \operatorname{Re} \leq 100$ and the equation $\alpha_{t}=0.3 \cdot\left(v \cdot d_{e} / v\right)^{0.9} \cdot(v / a)^{0.33} \cdot \lambda / d_{e}$ has been proposed to calculate the heat transfer coefficients, that is important for forecasting the heat energy costs at the filtration drying equipment design stage.
\end{abstract}

Keywords: solid biofuel, agricultural residues, renewable energy sources, drying agent, filtration drying, sunflower stems, thin-layer experiment, heat transfer coefficient, energy balance.

\section{Introduction}

Global energy demand is increasing every day. The most energy is produced from fossil fuels. Production of biogas [1-2] and solid biofuel [3], energy from various biomass feedstock such as forest wood [5], fallen leaves [5] and agricultural residues [6] is important and promising sectors of renewable energy sources both from economic and ecological standpoints. Ukraine has a large agricultural potential and, accordingly, the opportunity to obtain raw materials (straw, corn and sunflower stems) for the creation of all types of biofuel, which can significantly influence the energy dependence of the country and the conservation of energy resources in general. Therefore, the potential of agricultural residues as a raw material for solid bio-fuel production will increase significantly. The

\footnotetext{
${ }^{1}$ Lviv Polytechnic National University,

12, Bandery St., 79013 Lviv, Ukraine

kindzera74@ukr.net

(CKindzera D., Hosovskyi R., Atamanyuk V., Symak D., 2021
}

production of solid bio-fuel is a promising way to solve the following urgent environmental, economic and social problems: the use of surplus quantum of biomass residues; independence from fossil fuels; improvements in the state of the biosphere by cutting greenhouse gas emissions; supply of consumers with alternative energy sources; development and implementation of the modern energy technologies in accordance with the Energy Strategy of Ukraine by 2035 [7]. The practical use of solid bio-fuel creates new market opportunities in the agricultural sector.

Currently, sunflower (Helianthus annuus L.) is one of the most economically important oilseed crops in the world including most European countries and Ukraine with advantages of low input cultivation, high crop yield and wide adaptation to climatic and soil conditions [8]. Taking into account that today only the sunflower seeds are used, $95 \%$ of the produced biomass is wasted. Sunflower stems (the main part of sunflower biomass), are not currently exploited but they are of great interest. Current waste management techniques for sunflower stems involve incineration and landfilling. The lignocellulosic nature of sunflower stems presents opportunities for valorization them into clean and renewable bioenergy, especially for using them as a raw material for solid biofuel production. However, sunflower stems which have the height of 1-3 $\mathrm{m}$ and high moisture content, should be grinded and dried before pressing to improve the solid biofuel production. As the result of drying process, moisture content of grinded sunflower biomass should be reduced from $35-65 \%$ (depending on type, place, period of logging and storing duration) to $4-12 \%$ [9].

Drying is the most common heat and mass transfer process using a wide range of organic raw materials, including biomass. But the cost of drying is approximately $30 \%$ of total processing cost in most factories. Therefore, the level of solid biofuel technologies implementation in Ukraine remains unsatisfactory due to the lack of scientific and technical solutions to reduce energy consumption in production lines. Around $85 \%$ of all drying systems are based on convective method. The heat exchange processes between the drying agent and grinded biomass are limited by the low thermal conductivity of the material, and the mass transfer - by the intensity of 
moisture transfer from the cells to the intercellular space, as well as through the micro- and macropores to the drying agent [10].

The scientific understanding of heat and mass transfer is important for the development of more efficient dryers, since they could lead to the reduction in energy consumption. From a scientific point of view, drying of particulate solids and products is a complex process, which is characterized by interactions of heat and mass transfer occurring simultaneously between the particles or products and the drying medium. Therefore, the heat transfer coefficient is a key parameter to quantify the heat transfer. The values of the convective heat transfer coefficients of various agricultural products under open sun drying conditions were determined by Akpinar [11]. Grains, seeds, coffee, wood chips, coal and many chemical products, as well as grinded agricultural residues are usually dried by using fixed bed drying method [12, 13]. In most cases, fixed bed dryers are operated by passing drying agent over the solid surface. The values of heat transfer coefficients are low and drying agent does not completely transfer its energy to the solid that causes significant energy losses owing to outlet agent and long drying time. Messai et al. [14] experimentally determined the heat transfer coefficients in packed bed of rice, malt and barley, and they were found to be a function of gas flow rate. On the basis of thorough review of works on the theory of drying, several correlations were found in the literature to predict heat transfer coefficients in fixed beds [15]:

$$
\begin{aligned}
& N u_{p}=\left(0.5 \operatorname{Re}_{p}^{1 / 2}+0.2 \operatorname{Re}_{p}^{2 / 3}\right) \operatorname{Pr}^{2 / 3}\left(20<\operatorname{Re}_{p}<80000\right) ; \\
& \alpha=3.26 \cdot C_{p} \cdot G g \cdot \operatorname{Re}^{-0.65} \cdot \operatorname{Pr}^{2 / 3}(20<\operatorname{Re}<1000) ; \\
& \alpha=\left(C_{p} \cdot G g / \varepsilon\right) \cdot\left(2.876 / \operatorname{Re}+0.302 / \operatorname{Re}^{0.35}\right) \mathrm{Pr}^{-2 / 3}
\end{aligned}
$$

$(10<\operatorname{Re}<10000)$. Akpinar et al. [16] investigated the effect of the drying air temperature (313-343 K) and air velocity $(0.8-3.0 \mathrm{~m} / \mathrm{s})$ on convective heat transfer coefficients during the thin layer drying process of ginger slices by using cyclone type convective dryer. Convective heat transfer coefficients of ginger slices showed changes within $0.33-2.11 \mathrm{~W} / \mathrm{m}^{2} \cdot \mathrm{K}$. A model equation for predicting heat transfer coefficient of air in a batch dryer using BuckingHam Pi-theorem and dimensional analysis at various air velocities has been formulated by Emenike et al. [17]. It was validated by drying unripe plantain chips in a batch dryer at air velocities of $0.66-1.20 \mathrm{~m} / \mathrm{s}$ within the temperature range of 315-339 K. The comparison of both experimental and modeled heat transfer coefficients $\left(31.64 \mathrm{~W} / \mathrm{m}^{2} \cdot \mathrm{K}\right.$ against $\left.34.85 \mathrm{~W} / \mathrm{m}^{2} \cdot \mathrm{K}\right)$ shows a percentage error of $9.22 \%$ which is within acceptable level. In rotary and fluidized bed dryers, which are used in industry for the drying of mentioned before materials, each particle of the dispersed material is surrounded by the gas stream resulting in higher mass and heat coefficients, but high capital and operating costs. A large consumption of energy is a main disadvantage of such kind of equipment $[18,19]$.

Since the costs for drying represents a significant part of solid biofuel manufacturing cost, improving efficiency or finding alternative drying methods with designing new constructions of dryers is an urgent task. Generally, during the operation of filtration dryers, the drying agent is blown downward through the complex network of channels of different diameters and considerable lengths formed by voids between the particles of the material located on a perforated belt. The developed surface of the fixed bed facilitates good contact between the drying agent and material particles, so almost all heat energy remains in the material layer intensifying the heat and mass processes. The proven fact is that the drying agent temperature and the velocity intensify the process. Thus, the filtration drying method gives an opportunity to use low temperature drying agent in wide range of velocities without fluidization of the particles. The amount of heat given by the drying agent to the fixed bed per unit time is higher than in the case of passing drying agent over the solid surface. The result is higher values of the heat transfer coefficients. Therefore, filtration drying method gives an opportunity to intensify mass and heat transfer processes and to reduce the drying agent amount, drying time and energy loss through outlet drying agent.

The phenomenon of heat and mass transfer between the drying agent and different dispersed materials [20], as well as organic materials like grain [21], pumpkin [22], grinded energy willow [23] has been studied during the filtration drying by many scientists who created criteria equations to predict heat transfer coefficients. However, the equations are valid only for investigated materials and cannot be used to calculate heat transfer coefficients during the filtration drying of grinded sunflower stems in view of considerable difference between experimental and calculated results.

So, the aim of this work is to determine the heat transfer coefficients from the drying agent to the fixed bed of grinded sunflower stems during the filtration drying and to estimate the equation that allows to calculate them at different actual velocities of gas flow.

\section{Experimental}

\subsection{Materials}

Sunflower stems were used as a raw material for solid biofuel production taking into account a chemical composition with high amount of cellulose $(41.8 \%)$, hemicelluloses $(21.3 \%)$ and lignin $(20.1 \%)$. As a result, the higher heating values (HHVs) varied from 17 to 
$20 \mathrm{MJ} / \mathrm{kg}$ according to the moisture content. Initial moisture content of grinded sunflower stems was conditioned by the presence of free (capillary) moisture in the cells cavity and intercellular space, as well as bounded moisture in the cell walls. Stems were mechanically grinded in jaw crusher to increase the biomass surface area and to facilitate the drying process. In order to obtain particles distribution, material was screened to seven fractions and content of each fraction was determined (Table 1).

Table 1

Particles distribution of grinded sunflower stems

\begin{tabular}{|c|c|c|c|c|c|c|c|}
\hline Fraction size, $\mathrm{mm}$ & $0.01-0.16$ & $0.16-0.315$ & $0.315-0.63$ & $0.63-1.25$ & $1.25-2.5$ & $2.5-5.0$ & $>5.0$ \\
\hline Fraction content, \% & 2.2 & 10.4 & 15.8 & 29.9 & 9.3 & 28.8 & 3.6 \\
\hline
\end{tabular}

\subsection{Experimental Procedure}

\subsubsection{Fixed bed formation}

To determine the heat transfer coefficients, the experiments were performed using a container with internal diameter of $97 \mathrm{~mm}$ (Fig. 1) as the main part of the experimental setup represented in [20]. The container base (1) was made of aluminum and equipped with dural perforated bottom (2) and thermal insulating insert (3) made of fluoroplast to eliminate heat losses through walls. The fixed bed of grinded sunflower stems (4) with $10 \mathrm{~mm}$ in length, porosity $\varepsilon=0.4 \mathrm{~m}^{3} / \mathrm{m}^{3}$, the specific surface area $a=4200 \mathrm{~m}^{2} / \mathrm{m}^{3}$ and equivalent diameter of the channels $d_{e}=0.376 \cdot 10^{-3} \mathrm{~m}$ was formed.

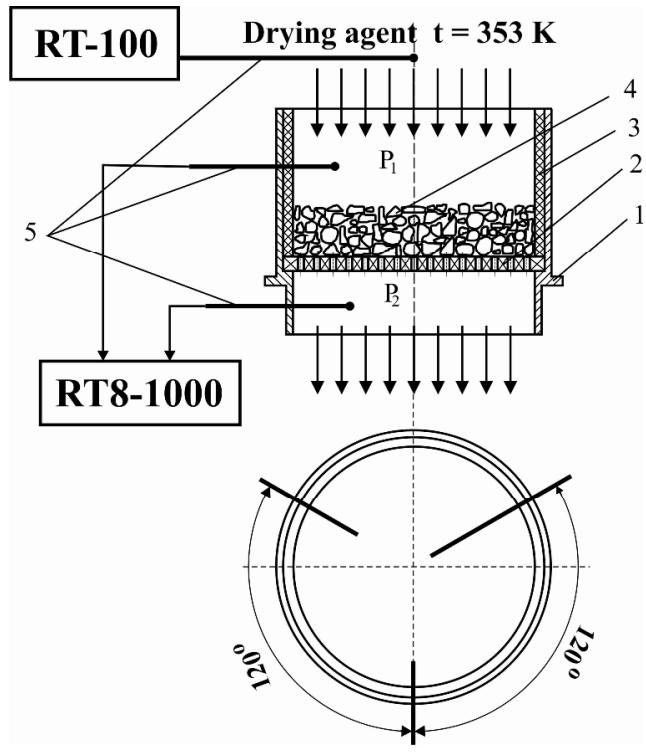

Fig. 1. A schematic diagram of container as the part of the experimental setup: container base (1); perforated bottom

(2); thermal insulating insert (3) and fixed bed of grinded sunflower stems (4)

\subsubsection{Methodology of the researches}

Experimental method is the most conclusive for the determination of heat transfer coefficients in a real drying system or at the experimental setup representing the real system. It entails creating a suitable geometry of the fixed bed, pumping the drying agent through it and using thermocouples to measure temperatures at the inlet and outlet of the fixed bed. Thin-layer experiments are used for heat transfer coefficients determination. For this purposes fixed bed of dispersed material about $10 \mathrm{~mm}$ in length must be formed. When drying agent is filtered through the thin layer, it is uniformly distributed throughout the layer volume. The behavior of heat which is supplied by the drying agent is similar. As the result, all bulk of material participates in the heat transfer process. In several seconds (depending on the drying agent velocity), the temperature of the drying agent at the outlet of the material becomes quite close to its inlet temperature which indicates that the process driving force becomes minimal.

The drying agent temperature of $353 \mathrm{~K}$ was found to be the optimum one as the result of the energy costs calculations. Thus, according to the scheme (Fig. 1), an air was supplied by a blower, heated in a heater to $353 \mathrm{~K}$ and filtered through the fixed bed of grinded sunflower stems (4). A control system allows setting the drying agent temperature. The constant temperature at the fixed bed inlet was $353 \pm 0.5 \mathrm{~K}$ and was controlled using thermoregulator RT-100 and chromel-copel thermocouple. Steady-state conditions were reached. Flow rate of the drying agent was registered by the electronic flow-meter RPF-I and controlled by flow-regulating valves. The experiments were conducted at actual velocities ranging from 0.68 to $2.05 \mathrm{~m} / \mathrm{s}$. So, the fixed bed (granular medium made of solid particles) was crossed by the gas phase.

To determine the drying agent temperatures at the inlet and outlet of the fixed bed, six thermocouples were used. Three of them were installed at a distance of $0.2 \mathrm{~m}$ from the drying agent inlet and three of them were installed at a distance of $0.2 \mathrm{~m}$ from the outlet perforated bottom. Thermocouples were installed at an angle of $120^{\circ}$ to each other at the distance of $0.1,0.2$ and $0.3 \mathrm{~m}$ from the container center. The temperatures were automatically recorded using temperature indicator RT8-1000 with data computer processing. The experiments were finished 
when the temperature at the fixed bed outlet was close to $353 \mathrm{~K}$. Every experiment was carried out three times to obtain the reliable data.

\section{Results and Discussion}

\subsection{Experimental Curves}

Thin-layer bed experiments were conducted according to the experimental procedure described in Section 2 and experimental curves are presented in Fig. 2. Data from three experimental runs were used. Horizontal line in the top of the graphs indicated by specific symbol shows the temperature of $353 \mathrm{~K}$ (the constant temperature at the fixed bed inlet).

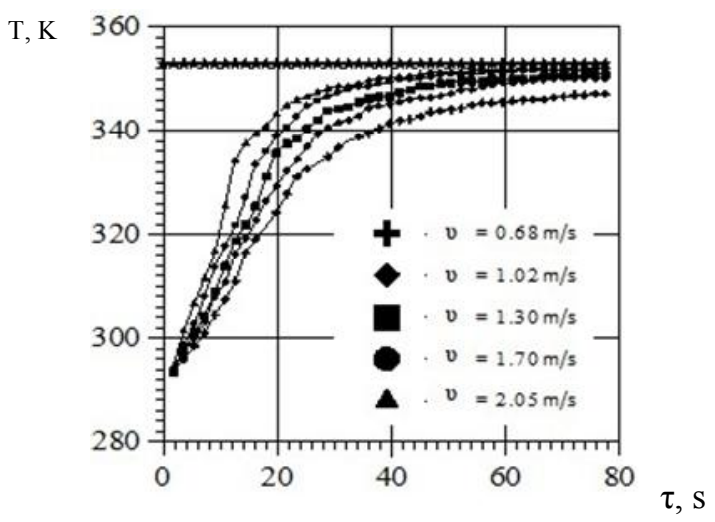

Fig. 2. Drying agent temperature at the outlet of the fixed bed $v s$. time at different actual velocities (length of the fixed bed $H=10 \mathrm{~mm}$ )

In several seconds (depending on the drying agent velocity), the temperature of the drying agent at the outlet of the material becomes quite close to its inlet temperature which indicates that the process driving force becomes minimal. The increase in the drying agent velocity increases the heat amount given to the fixed bed over a certain period of time and intensifies the heat transfer process. It is evident from Fig. 2, that at the actual velocity of $2.05 \mathrm{~m} / \mathrm{s}$ the drying agent temperature close to $353 \mathrm{~K}$ was achieved at the outlet of the fixed bed after 60 $\mathrm{s}$ from the beginning. The obtained results allow to calculate the values of the heat transfer coefficients from the drying agent to the particles of the fixed bed according to Eq. (1).

\subsection{Determination of Heat Transfer Coefficients}

The heat transfer coefficient $\alpha$ which determines the amount of heat donated or accepted by the surface unit for time unit is an important thermal characteristic of the heat transfer processes. However, the coefficients will have different values for different types of grinded biomass (in view of different structure of the fixed beds) at the equal values of drying agent parameters (temperatures and velocities).

The values of heat transfer coefficient were calculated on the basis of the obtained experimental data given in Fig. 2 in accordance with following equation [20]:

$$
\alpha=\frac{\Delta Q}{F \cdot\left(\bar{t}-\bar{T}_{p .}\right) \cdot \Delta \tau}
$$

where $\Delta Q$ is an amount of heat remaining in the fixed bed, $\mathrm{J} ; \bar{t}$ is an average temperature of the drying agent at the inlet and outlet of the fixed bed, $\mathrm{K}$ (in accordance with the measurements given in Fig. 2); $\Delta \tau$ is an experimental time, $\mathrm{s} ; \overline{T_{p}}$ is an average surface temperature of the particles, $\mathrm{K} ; F$ is a fixed bed surface, $\mathrm{m}^{2}$.

Amount of heat remaining in the fixed bed may be determined using the equation of energy balance:

$$
\Delta Q=m \cdot c_{s} \cdot\left(\bar{T}-T_{0}\right)
$$

where $T_{0}$ is an average initial temperature of the particles, $\mathrm{K} ; m$ is the mass of all particles in the fixed bed, $\mathrm{kg} ; c_{s}$ is heat capacity of the particles, $\mathrm{J} / \mathrm{kg} \mathrm{K} ; \bar{T}$ is an average temperature of particles inside the fixed bed.

Obviously, the average surface temperature of the particles is higher than that of particles inside the fixed bed $\left(\bar{T}_{p .}>\bar{T}\right)$. However, it should be pointed out that the average surface temperature of the particles can not be measured experimentally and it is estimated as follows.

Takin into account that during the filtration dryer operation, the drying agent is supplied to the dryer and passes through the fixed bed, it may be assumed that:

- the drying agent uniformly flows around the surface of each particle;

- the drying agent temperature is the same from all sides of each particle;

- distribution of the temperature field through the whole volume of each particle is parabolic.

According to above mentioned assumptions, the average surface temperature of the particles may be determined from Eq. (3) [20]:

$$
\bar{T}_{p}=t-\left(t-T_{0} \cdot e^{-\mu_{1}^{2} \cdot F o}\right) \cdot\left(1-\frac{r}{R}\right) \cdot e^{-\mu_{1}^{2} \cdot F o}
$$

where $t$ is the drying agent temperature, $\mathrm{K} ; R$ and $r$ are average radius of particles and radius of heat extension inside the particles, respectively $(0<r \leq R), \mathrm{m} ; F_{O}$ is Fourier number.

Under accepted drying conditions and values of Fourier number $\left(F_{0}>0,3\right.$ regular regime $)$, we limit ourselves by the first root $\mu_{1}$ of Eq. (3). 
Therefore, based on the experimental data given in Fig. 2 and taking into account Eqs. (2) and (3), the values of heat transfer coefficients $\alpha$ from the drying agent to the particles of grinded sunflower stems were calculated according to Eq. (1). The graphic dependence of heat transfer coefficients versus drying agent velocities $\alpha=f(v)$ is plotted on the basis of calculated results (Fig. 3).

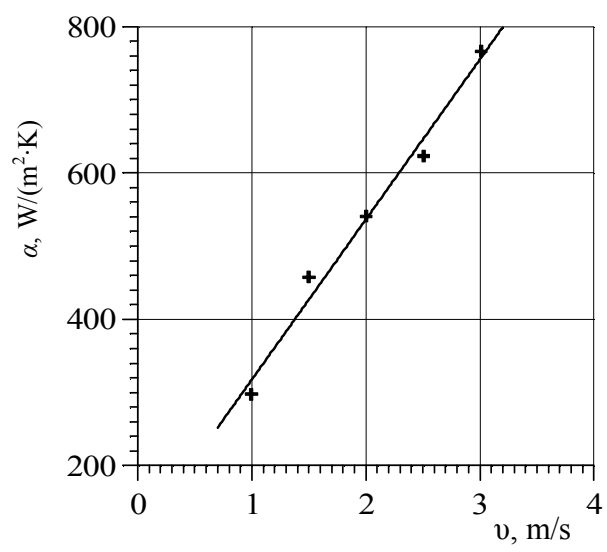

Fig. 3. Heat transfer coefficients $v s$. actual velocities of the drying agent

The hydrodynamics of the drying agent flow through the fixed bed is extremely complex, since the channels formed by voids between particles change their directions and cross-sectional areas. This causes constant changes in drying agent velocities. Therefore, values of the heat transfer coefficients are averaged over the fixed bed. The graph which is shown in Fig. 3 has practical application and allows to determine the values of heat transfer coefficients during filtration drying of grinded sunflower stems, that is important for forecasting the heat energy costs at the drying equipment design stage.

The values of heat transfer coefficients for sunflower stems were compared with coefficients obtained by Atamanyuk and Gumnytsky [20] for different dispersed materials under filtration drying conditions. Comparison was made within the velocities range of $2-3.5 \mathrm{~m} / \mathrm{s}$ (Table 2).

Results represented in Table 2 show that values of heat transfer coefficients for different dispersed materials which were dried in filtration dryer are higher than for the materials dried in other types of dryers which were mentioned before [16, 17]. Industrial filtration dryers, in which the drying agent is filtered downward through the material located on a perforated belt, are able to use lowtemperature drying agent to achieve higher values of the heat transfer coefficients. So, the filtration drying method has significant economic advantages. Moreover, the application of the filtration drying method with lowtemperature drying agent gives the opportunity to reduce the fire risk during biomass drying and to minimize emissions of the heat energy and solid particles into the working area of the enterprises.

Heat transfer coefficients for different materials under filtration drying conditions

\begin{tabular}{|c|c|c|}
\hline Material & Values of heat transfer coefficient $\alpha, \mathrm{W} /\left(\mathrm{m}^{2} \cdot \mathrm{K}\right)$ & Ref. \\
\hline Medium-grained sand & $40-70$ & {$[20]$} \\
\hline Coarse-grained sand & $95-170$ & {$[20]$} \\
\hline Coal $d=(0.31-0.63) \cdot 10^{-3} \mathrm{~m}$ & $70-130$ & {$[20]$} \\
\hline Coffee sludge & $93-165$ & {$[20]$} \\
\hline Peat & $100-190$ & {$[20]$} \\
\hline Coal $d=(5-10) \cdot 10^{-3} \mathrm{~m}$ & $220-430$ & {$[20]$} \\
\hline Grinded sunflower stems & $540-855$ & This work \\
\hline
\end{tabular}

\subsection{Generalization of the Results}

Analysis of the obtained results has shown that the drying agent velocity has a significant impact on the heat transfer process during the filtration drying of the biomass. Therefore, it would be useful to generalize the experimental results to obtain the equation which allows to calculate theoretically the heat transfer coefficients, that is important for forecasting the heat energy costs at the drying equipment design stage.

Some empirical equations for predicting the heat transfer coefficient in packed beds are available in order to obtain the best reproduction of the experimental data. However, they are valid only for investigated materials and cannot be used for calculations of heat transfer coefficients during filtration drying of grinded sunflower stems.

Using the methods of similarity theory, the dependence of heat transfer coefficient on many factors can be represented as compact relations between dimensionless parameters, known as similarity criteria.

So, the experimental data were generalized in accordance with Eq. (4) [20]:

$$
\begin{array}{r}
\mathrm{Nu}=f(\mathrm{Re}, \mathrm{Pr}) \\
\mathrm{Nu}=A \cdot \mathrm{Re}^{n} \cdot \operatorname{Pr}^{m}
\end{array}
$$

where $_{\mathrm{Nu}}=\frac{\alpha \cdot d_{e}}{\lambda}, \operatorname{Re}=\frac{v \cdot d_{e}}{v}, \operatorname{Pr}=\frac{v}{a}$ are Nusselt, Reynolds and Prandtl numbers, respectively; $d_{e}$ is an equivalent diameter of channels in the fixed bed, $\mathrm{m} ; \lambda$ is thermal conductivity 
of the drying agent, $\mathrm{W} /(\mathrm{m} \cdot \mathrm{K}) ; v$ is kinematic viscosity of the drying agent, $\mathrm{m}^{2} / \mathrm{s} ; \alpha$ is thermal diffusivity of the drying agent, $\mathrm{m}^{2} / \mathrm{s}$.

The values of the coefficient $A$ and exponents $n$ and $m$ should be experimentally determined. According to the recommendations and taking into account that the physical parameters of the drying agent are changed within the narrow range, we assume $\mathrm{Nu} \sim \operatorname{Pr}^{0.33}[20]$. So, the exponent $m=0.33$. To determine the coefficient $A$ and exponent $n$ in Eq. (5) the experimental data were plotted as the dependence $\mathrm{Nu} / \mathrm{Pr}^{0.33}=f(\mathrm{Re})$ in the logarithmic coordinates (Fig. 4). The value of the coefficient $A$ is equal to 0.3 and exponent $n$ is equal to 0.9 .

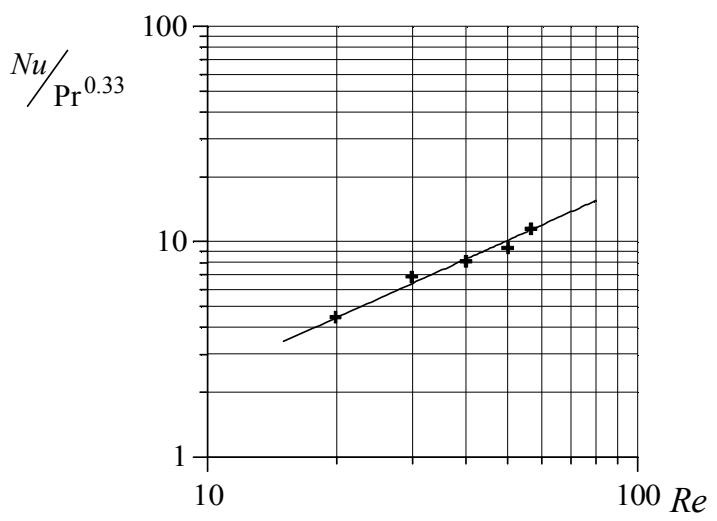

Fig. 4. Generalization of the experimental results: $\mathrm{Nu} / \mathrm{Pr}^{0.33}$ vs. Reynolds number

Therefore, taking into account the values of $A, m$ and $n$, Eq. (5) takes a form:

$$
N u=0.3 \cdot \operatorname{Re}^{0.9} \cdot \operatorname{Pr}^{0.33}
$$

Since the Nusselt number includes the value of the heat transfer coefficient, the Eq. (6) may be represented as:

$$
\alpha_{t}=0.3 \cdot\left(\frac{v \cdot d_{e}}{v}\right)^{0.9} \cdot\left(\frac{v}{a}\right)^{0.33} \cdot \frac{\lambda}{d_{e}}
$$

Therefore, the deduced Eq. (7) makes it possible to calculate theoretically with sufficient accuracy the heat transfer coefficients during the filtration of the drying agent through the fixed bed of sunflower stems within the Reynolds number range of $20 \leq \operatorname{Re} \leq 100$, to predict the required thermal energy consumption during the design stage of the drying equipment and to choose the rational parameters of the filtration process.

The correlation dependence $\alpha_{\exp }$ (experimental data (Fig.3)) versus $\alpha_{t}$ (theoretically calculated according to the Eq. (7)) is shown in Fig. 5.

Maximum relative error between experimental (Fig. 3) and theoretical values of the heat transfer coefficients (Eq. (7)) does not exceed $\pm 7.5 \%$. Taking into account that fixed bed was formed by particles with different structure (as the result of stems grinding which are formed from several fibers), as well as particles size distribution (Table 1), the maximum relative error has acceptable level.

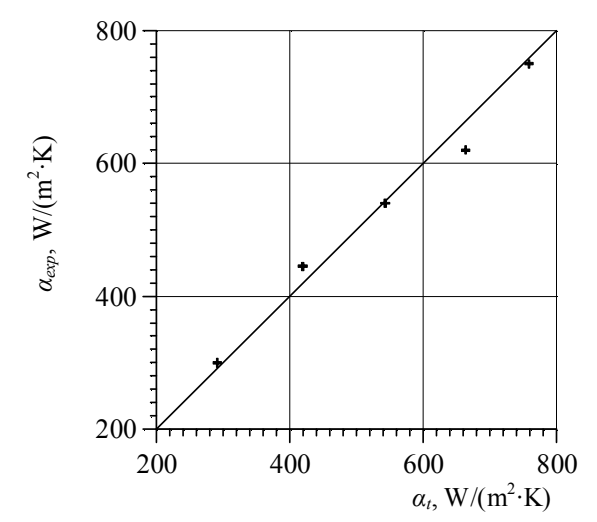

Fig. 5. Correlation dependence $\alpha_{\exp } v s . \alpha_{t}$

\section{Conclusions}

Taking into account the advantages and the disadvantages of rotary, fluidized bed and belt dryers, the filtration dryer has been introduced for grinded sunflower stems drying in view of the possibility to achieve higher values of the heat transfer coefficients and due to its expected lower energy consumption.

The effect of the increasing drying agent velocity from 0.68 to $2.05 \mathrm{~m} / \mathrm{s}$ on the heat transfer intensity has been established by conducting thin-layer experiments. The values of heat transfer coefficients have been calculated on the basis of the thin-layer experimental data and equation $\alpha=\Delta Q / F \cdot\left(\bar{t}-\bar{T}_{p}\right) \cdot \Delta \tau$. They were found to be $540-855 \mathrm{~W} /\left(\mathrm{m}^{2} \mathrm{~K}\right)$. The calculated coefficients for grinded sunflower stems have been correlated by the dimensionless expression $N u=0,3 \cdot \operatorname{Re}^{0,9} \cdot \operatorname{Pr}^{0,33}$ within the Reynolds number range of $20 \leq \operatorname{Re} \leq 100$

The proposed equation $\alpha_{t}=0.3 \cdot\left(v \cdot d_{e} / v\right)^{0.9} \cdot(v / a)^{0.33} \cdot \lambda / d_{e}$ allows to calculate theoretically the heat transfer coefficients within Reynolds number range of $20 \leq \operatorname{Re} \leq 100$, that is important for forecasting the heat energy costs at the filtration drying equipment design stage.

Maximal relative error between experimental and theoretical values of the heat transfer coefficients does not exceed $\pm 7.5 \%$. Taking into account a complex structure of the fixed bed formed by particles of sunflower stems, the maximal relative error has acceptable level for predicting heat transfer coefficients.

The proposed method for determination of heat transfer coefficients will be useful when modeling and 
designing the filtration drying equipment, as well as when determining filtration drying optimal parameters for different kinds of grinded biomass.

\section{References}

[1] http://agravery.com/uk/posts/show/12

[2] Deublein D., Steinhauser A.: Biogas from Waste and Renewable Resources. Wiley-VCH 2008.

https://doi.org/10.1002/9783527621705

[3] Hejnfelt A., Angelidaki I.: Biomass Bioenerg., 2009, 33, 1046. https://doi.org/10.1016/j.biombioe.2009.03.004

[4] Brostow W., Menard K., Menard N.: Chem. Chem. Technol., 2009, 3, 173.

[5] Nyakuma B., Oladokun O.: Chem. Chem. Technol., 2017, 11, 392. https://doi.org/10.23939/chcht11.03.392

[6] Nyakuma B.: Environ. Climate Technol., 2015, 15, 77. https://doi.org/10.1515/rtuect-2015-0007

[7] Pavliukh L., Boichenko S., Onopa V. et al.: Chem. Chem. Technol., 2019, 13, 101. https://doi.org/10.23939/chcht13.01.101

[8] Halyshko V.: Monitoring Birzhovogo Rynku, 2014, 3, 6.

[9] Gosovskiy R., Kindzera D., Atamanyuk V.: Chem. Chem. Technol., 2016, 10, 459. https://doi.org/10.23939/chcht10.04.459 [10] Kindzera D., Atamanyuk V., Hosovskyi R.: Visnyk Odesa Nats. Acad., 2015, 42, 194.

[11] Akpinar E.: Int. Commun. Heat Mass Transfer, 2004, 31, 585. https://doi.org/10.1016/S0735-1933(04)00038-7

[12] Resio A., Aguerre, R., Suarez C.: Braz. J. Chem. Eng., 2005,

22, 303. https://doi.org/10.1590/S0104-66322005000200019

[13] Faria L., Rocha S.: Braz. J. Chem. Eng., 2000, 17, 4. https://doi.org/10.1590/S0104-66322000000400013

[14] Messai S. et al.: Therm. Sci., 2014, 18, 443.

https://doi.org/10.2298/TSCI120715108M

[15] Prado M., Sartori D.: Braz. J. Chem. Eng., 2008, 25, 39. https://doi.org/10.1590/S0104-66322008000100006

[16] Akpinar E., Toraman S.: Heat Mass Transfer, 2015, 52, 1. https://doi.org/10.1007/s00231-015-1729-6

[17] Wami E., Ibrahim M.: Int. J. Sci. Eng. Res., 2014, 5, 121.

[18] Snezhkin Yu., Korinchuk D., Vorobiov L., Kharin O.: Prom.

Teplotechn., 2006, 28, 41.
[19] Kindzera D., Atamanyuk V., Pelekh M., Hosovskyi R.: Chem., Technol. Appl. Substances, 2019, 2, 110.

https://doi.org/10.23939/ctas2019.01.110

[20] Atamanyuk, V., Gumnytsky Ya.: Naukovi Osnovy

Filtracijnogo Sushinnya Dispersnykh Materialiv. Vyd-vo Lviv Polytech., Lviv 2013.

[21] Atamanyuk V., Matkivska I., Barna I.: Visnyk Nats. Univ. "Lvivska politechnika". 2015, 812, 302.

[22] Atamanyuk V., Huzova I., Gnativ Z.: Food Sci. Technol., 2017, 11, 21. https://doi.org/10.15673/fst.v1 1i4.727

[23] Atamanyuk V. Humnyckyj Ja., Mosjuk M.: Naukovyj Visnyk NLTU Ukrainy, 2011, 21, 95.

Received: November 12, 2019 / Revised: December 01, 2019/ Accepted: January 24, 2020

\section{ТЕПЛООБМІН ПІД ЧАС \\ ФІЛЬТРАЦІЙНОГО ВИСУШУВАННЯ ПОДРІБНЕНОӤ БІОМАСИ СОНЯШНИКА}

Анотація. Запропоновано фільтраційне висушування подрібнених стебел сонямника, як стадї технологічної лінії для виробництва твердого біопалива. Проаналізовано теоретичні аспекти прочесів теплообміну під час фільтрачійного висушування. Встановлено вплив збільшення швидкості теплового агенту від 0,68 до 2,05 м/с на інтенсивність теплообміну. Значення коефіцієнтів тепловіддачі розраховані на основі даних експерименту у тонкому шарі та залежності $\alpha=\Delta Q / F \cdot\left(\bar{t}-\bar{T}_{p}\right) \cdot \Delta \tau$. Розраховані коефіиієнти для подрібнених стебел сонямника узагальнені за допомогою безрозмірної залежності $\mathrm{Nu}=0.3 \cdot \mathrm{Re}^{0.9} \cdot \operatorname{Pr}^{0.33}$ y межах діапазону чисел Рейнольдса $20 \leq \operatorname{Re} \leq 100$ та для розрахунку коефіиієнтів тепловіддачі запропоновано рівняння $\alpha_{t}=0.3 \cdot\left(v \cdot d_{e} / v\right)^{0.9} \cdot(v / a)^{0.33} \cdot \lambda / d_{e}$, яке є важливим для прогнозування затрат теплової енергї на етапі проектування обладнання для реалізайї фільтраційного висушування.

Ключові слова: тверде біопаливо, сільськогосподарські залишки, поновлювані джерела енергії, сушильний агент, фільтрачійне висушування, стебла соняшнику, експеримент у тонкому шарі, коефіцієнт тепловіддачі, енергетичний баланс. 